\title{
Micro-Credit Access and Profitability on Crop Production in Orhionmwon Local Government Area of Edo State, Nigeria
}

\author{
${ }^{* 1}$ EKUNWE, PA; ${ }^{1}$ OREWA, SI; ${ }^{2}$ ABULU, MO; ${ }^{1}$ EGWARE, RA \\ Department of Agricultural Economics and Extension Services, Faculty of Agriculture and Agricultural Technology, Benson Idahosa \\ University, Benin City, Edo State, Nigeria \\ Agricultural and Rural Development Secretariat, Federal Capital Territory Administration, Abuja, Nigeria
}

KEY WORDS: Micro-credits, Gross Margin, Profit, Crop Production, Edo State.

\begin{abstract}
This study focused on the effect of micro-credit on the profitability of crop production in Orhionmwon Local Government Area of Edo State, Nigeria. A sample size of 166 small-scale farmers was randomly selected from the farming communities in Orhionmwon Local Government Area. Ninety two (92) beneficiaries and 74 non-beneficiaries were randomly selected from the study area. A well-structured questionnaire and scheduled interviews were used to obtain data from the farmers. The data collected were subjected to descriptive statistics such as frequency counts, percentages and mean scores. The mean scores were compared using the t-test. Results showed that the respondents in the study area were almost uniformly distributed gender-wise. The females were however slightly more, both among the beneficiaries $(58.7 \%)$ and non-beneficiaries $(52.7 \%)$. The mean years of farming for both the credit beneficiaries and non-beneficiaries were 32 years and 34 years respectively. Most of the farmers had farm holdings less than 2.5 ha. The profit margin obtained from the beneficiaries was higher than that of the non-beneficiaries. For maize, it

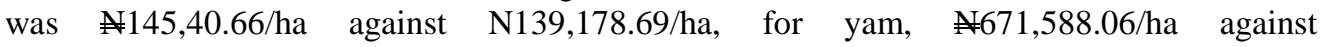
$\$ 552,927.93 / \mathrm{ha}$, for cassava $\$ 377,194.99 / \mathrm{ha}$ against $\$ 223,000.74 / \mathrm{ha}$ and for plantain \#681,416.68/ha against $\$ 430,756.59 /$ ha. Untimely delivery of loan was indicated as the greatest constraint to loan acquisition by the beneficiaries while the non-beneficiaries identified high interest rate charges by the microfinance bank and distance as the greatest reasons for not accessing loans. (C) JASEM
\end{abstract}

\section{http://dx.doi.org/10.4314/jasem.v19i1.11}

\section{Introduction}

Microfinance is a term used to refer to financial services focused on people with low incomes and small-scale businesses located either in the rural or urban area (USAID, 2005). Irobi (2008) defined microfinance as the provision of financial services such as credit (loans), savings, micro-leasing, microinsurance, and payment transfers to economically active poor and low income households to enable them engage in income generating activities or expand/grow their small businesses. Microfinance is defined as a financial intervention that focuses on the low-income group of a given society. The intervention primarily involves credit services and may also include savings, insurance on credits and savings. Robinson (2001) also defined micro finance as the supply of loans, savings and other basic financial services to the poor. Microfinance evolved as an economic development approach intended to benefit the low-income part of a given society, both men and women (Irobi, 2008).
According to Tchouassi (2011), the term refers to provision of financial services (including saving and credit) to the poor and vulnerable. Microfinance banks therefore are institutions that are established to provide financial services to the poor. Microfinance institutions can be non-governmental organizations, thrift and credit cooperatives, loan unions, government banks, commercial banks, or non-bank financial institutions (Ledgerwood, 1999). Nigerian farms are classified into small scale, medium scale and large scale. According to Upton (1992), farm size of less than 5 hectares should be classified as small, between 5 hectares -10 hectares as medium and more than 10 hectares as large scale.

In Orhionmwon local government area, the only micro-finance bank giving out soft loans is the Trust Fund Micro Finance Bank. It has been in existence there for over 3 years. This study seeks to answer the following research questions: how has MFBs faired in the provision of agricultural credit to small-holder farmers? What are the effects of such volume of loan on the production of small holder farmers and what 
are the constraints to securing loans from MFB? The objectives of this study were to examine the socioeconomic characteristics of the small-holder farmers in the study area, compare the profitability of credit beneficiaries and non-beneficiaries and then identify the constraints faced by beneficiaries and nonbeneficiaries in accessing credit facilities.

\section{METHODOLOGY}

Area and Scope of Study: The study was carried out in Orhionmwon Local Government Area of Edo State with headquarters at Abudu. The State is located in the rainforest belt of Nigeria between Longitudes $5^{\circ} \mathrm{E}$ and $6^{\circ} 42^{\prime}$ and Latitudes $5^{\circ} 45^{\prime} \mathrm{N}$ and $35^{\circ} \mathrm{N}$. It is bounded by Kogi State to the North, Delta State to the South, Ondo State to the West and again Kogi State to the East. Edo State occupies a total land mass of $17,820 \mathrm{~km}^{2}$ and has a population of $3,218,332$ by the 2006 population census figure. Orhionmwon local government area is one of the oldest and largest among the 18 Local Government Councils in the State. It has a landmass of approximately 41,319 square $\mathrm{km}$. (EDSG, 2012). The scope of the study focused on small-scale arable farmers, who cultivate maize, cassava, yam and plantain in the study area. Trust Fund Microfinance Bank is the only microcredit institution in the area that is servicing the credit needs of the small scale crop farmers in the study area.

Data Collection and Sampling Techniques: Primary and secondary data were utilized for the study. Primary data were collected using a well-structured questionnaire and interview schedules (for nonilliterate respondents). Secondary data consisting of list of credit beneficiaries as well as amount disturbed were obtained from the disbursing Microfinance institution. A sample size of two hundred (200) smallscale farmers was randomly selected from the farming communities in Orhionmwon Local Government Area. One hundred (100) credit beneficiaries and One hundred (100) nonbeneficiaries were randomly selected from the study area. Data list consisting of three hundred (300) credit beneficiaries from the study area was obtained from Trust Fund microfinance bank which is the only microfinance institution in the study area. Through a process of random sampling, they were assigned numbers each from one (1) to three hundred (300) in a sheet of paper which were placed in a box where one hundred beneficiaries were drawn at random without replacement to make up the list of the researcher's sample size for the beneficiaries

To get the required number of sample size (100) of the non-beneficiaries, the study area was demarcated into five farming communities and twenty (20) nonbeneficiary farmers were drawn from among the nonbeneficiary farmers that were presented in each community. The non-beneficiaries were identified by scheduled meetings with the farmers either as individuals or as group living within the same locality as the beneficiaries. This made a total sample size of two hundred (200) consisting of one hundred (100) beneficiaries and one hundred (100) nonbeneficiaries. However, eight and 26 copies of the questionnaire administered to the beneficiaries and non-beneficiaries respectively were discarded since they were found to be unsuitable at the data analysis stage. Thus, 92 copies and 74 copies were analysed for the beneficiaries and non-beneficiaries respectively. This gave a response rate of $83 \%$.

Analytical Techniques: The data collected were subjected to descriptive statistics. The descriptive statistics used were frequency counts, percentages and mean scores. Gross margin analysis was used in determining the respondents' profitability accruing from sales of their farm produce. The arithmetical relations used in capturing profitability made are presented below in a step-wise fashion:

Total Cost $(\mathrm{TC})=$ Total Fixed Cost $(\mathrm{TFC})+$ Total
Variable Cost TVC)
Total Revenue $(\mathrm{TR})=$ Total Farm Output $(\mathrm{TFO}) \mathrm{x}$
Unit Price $(\mathrm{UP})$
Gross Margin $(\mathrm{GM})=\mathrm{TR}-\mathrm{TVC}$

\section{RESULTS AND DISCUSSION}

The results of the socioeconomic characteristics of the respondents are presented in Table I. Results showed that the respondents in the study area were fairly uniformly distributed gender-wise. The females were however slightly more, both among the beneficiaries $(58.7 \%)$ and non-beneficiaries $(52.7 \%)$. This indicates that though both males and females were involved in farming, the females appear to be more involved in providing food security. This is supported by the findings of Adisa and Okunade (2005) who reported that women contribute 60 per cent of the labour force, produce 80 percent of the nation's food, earn 10 percent of the money income

\footnotetext{
${ }^{* 1}$ EKUNWE, PA; ${ }^{1}$ OREWA, SI; ${ }^{2}$ ABULU, MO; ${ }^{1}$ EGWARE, RA
} 
but own only 1percent of the farm assets. Moreover, about 81.5 percent of beneficiaries were married while 56.8 percent of the non-beneficiaries were married. Onemolease (2001) in his study suggested that a possible explanation for the dominance of married farmers amongst respondents is to care for their families. It is also believed that a married person is more responsible and stable than the unmarried.

The age distribution among the respondents ranged between less than 30 and 70 years. Although there was a wide variation in age among the respondents; the average age was 45 years and 42 years for the credit beneficiaries and non-beneficiaries respectively. Only about $16 \%$ of the respondents were above 60 years of age while about $42 \%$ and $54 \%$ of the credit beneficiaries and non-beneficiaries respectively were 40 years of age and below. This implies that more youths were involved in arable crop farming in the study area.

The result from the survey further shows that only $24 \%$ of the credit beneficiaries had no formal education while illiteracy level among the nonbeneficiaries was as high as $40.5 \%$. This fact is in line with a similar study on microfinance Scheme in Western Nigeria by Oke et. al., (2007) in which they reported that 81 percent of the respondents had formal education. That study concluded that the high level of literacy was likely to afford respondents better managerial skills in handling their businesses. The relatively high level of illiteracy among the nonbeneficiaries in this study may be partly the reason why they could not access credit since they had less access to information. This fact is in line with the study of Asiabaka (2002) who reported that the resultant effect of lack of formal and informal education is acute resistance to change especially in the spread of information.

The result also indicated that majority of the respondents had farming experience of 40 years and above for both groups. These farmers can rightly be classified as "professionals" in farming business because of their long involvement in the farming business. The mean years of farming for both the credit beneficiaries and non-beneficiaries were 32 years and 34 years respectively.
The household size is the number of persons belonging to one household. This could include extended family members or other persons putting up with the family. The study revealed that most of the respondents had household sizes of between five to nine persons per household for both the credit beneficiaries $(52.2 \%)$ and non-beneficiaries $(54.1 \%)$ respectively. The mean household size was however eight persons per household for the beneficiaries while that of the non-beneficiaries was five persons per household. The large household size among beneficiaries may be a result of their increased labour need for their expanded farming operations. Dipeolu, et. al., (2000) was of the view that a larger household may serve as an important source of farm labour supply and consequently increased productivity.

The study further shows that $72.8 \%$ of beneficiaries and $89.2 \%$ of non-beneficiaries had farm sizes of less than 2.5 hectares, which is in line with the report of Akangbe (2012) which posits that close to 50 percent of Nigerian farmers cultivate between 1 - 5 hectares farmland and that they are generally small holder farmers.

Comparison of the Profit of Beneficiaries and NonBeneficiaries from the Cultivated Crops:

Profitability for Maize Production: The revenue and production costs incurred for maize production by credit beneficiaries and non-beneficiaries are presented on Table IIa. The amounts invested in maize production by both beneficiaries and nonbeneficiaries were $\$ 50,053$.14/ha and $\$ 29,127$.70/ha respectively, while the total revenue realized was $\$ 195,456.8 /$ ha and $\$ 168,306.39 /$ ha respectively. The results indicate that credit beneficiaries earned a profit of $\$ 145,403.66 /$ ha while non-beneficiaries realized $\$ 139,178.69 /$ ha as profit margin from maize production. The higher profit margin for credit beneficiaries suggests that access to credit contributed positively to the profit margin in maize production.

Profitability for Yam Production: The revenue and production costs incurred for yam production by credit beneficiaries and non-beneficiaries are represented on Table IIb. The total production costs invested in yam production were \$94,499.4/ha and $\$ 70,426.17 /$ ha by credit beneficiaries and nonbeneficiaries respectively while the gross income

\footnotetext{
${ }^{* 1}$ EKUNWE, PA; ${ }^{1}$ OREWA, SI; ${ }^{2}$ ABULU, MO; ${ }^{1}$ EGWARE, RA
} 
realized are \$766,087.46/ha and \$623,354.10/ha respectively. The Results indicate

that credit beneficiaries earned a profit of N671,588.06/ha, while non-beneficiaries realized \#552.927.93/ha as profit from yam production. This suggests that access to credit enhances farmers profit in yam production.

Profitability for Cassava Production: The revenue and production costs incurred for cassava production by credit beneficiaries and non-beneficiaries are presented on Table IIc. The results indicate that credit beneficiaries earned a profit of $\$ 377,194.99 / \mathrm{ha}$, while non-beneficiaries realized $\$ 223,000.74 /$ ha as profit from cassava production. This suggests that access to credit enhances farmers profit in cassava production.

Profitability for Plantain Production: The revenue and production costs incurred for plantain production by credit beneficiaries and non-beneficiaries as presented on Table II d. The results indicate that credit beneficiaries earned a profit of $\$ 681,416.68 / \mathrm{ha}$, while non-beneficiaries realized $\$ 430,756.59 /$ ha as profit from plantain production. This suggests that access to credit enhances farmers profit in plantain production.

Table 1: Socio-Economic Characteristics of Respondents

\begin{tabular}{|c|c|c|c|c|c|c|c|}
\hline \multirow[t]{2}{*}{ Characteristics } & \multirow[t]{2}{*}{ Categories } & \multicolumn{2}{|c|}{ Beneficiary $(n=92)$} & \multicolumn{4}{|c|}{ Non - beneficiary $(n=74)$} \\
\hline & & Freq & $\%$ & $\begin{array}{c}\text { Mea } \\
n\end{array}$ & Freq & $\%$ & $\begin{array}{c}\text { Mea } \\
n\end{array}$ \\
\hline \multirow[t]{2}{*}{ Sex } & Male & 38 & 41.3 & & 35 & 47.3 & \\
\hline & Female & 54 & 58.7 & & 39 & 52.7 & \\
\hline \multirow[t]{5}{*}{ Marital status } & Single & 3 & 3.3 & & 9 & 12.2 & \\
\hline & Married & 75 & 81.5 & & 42 & 56.8 & \\
\hline & Divorced & & & & 14 & 18.9 & \\
\hline & Widowed & 14 & 15.2 & & 6 & 8.1 & \\
\hline & Separated & & & & 3 & 4.1 & \\
\hline \multirow[t]{5}{*}{ Age range } & 30 years $\&$ below & 9 & 9.8 & & 20 & 27.0 & \\
\hline & $31-40$ & 30 & 32.6 & & 20 & 27.0 & \\
\hline & $41-50$ & 17 & 18.5 & & 7 & 9.5 & \\
\hline & $51-60$ & 21 & 22.8 & & 15 & 20.3 & \\
\hline & $>60$ years & 15 & 16.3 & 45 & 12 & 16.2 & 42 \\
\hline \multirow[t]{4}{*}{ Education } & No formal education & 24 & 26.1 & & 30 & 40.5 & \\
\hline & Primary education & 37 & 40.2 & & 23 & 31.1 & \\
\hline & Secondary education & 26 & 28.3 & & 17 & 23.0 & \\
\hline & Tertiary education & 5 & 5.4 & & 4 & 5.4 & \\
\hline \multirow[t]{2}{*}{ Farming status } & Part-time & 17 & 18.5 & & 16 & 21.6 & \\
\hline & Full time & 75 & 81.5 & & 58 & 78.4 & \\
\hline Farming & $1-10$ & 11 & 12.0 & & 5 & 6.8 & \\
\hline \multirow[t]{4}{*}{ experience range } & $11-20$ & 13 & 14.1 & & 6 & 8.1 & \\
\hline & $21-30$ & 8 & 8.7 & & 14 & 18.9 & \\
\hline & $31-40$ & 21 & 22.8 & & 19 & 25.7 & \\
\hline & $>40$ & 39 & 42.4 & 32 & 30 & 40.5 & 34 \\
\hline Household size & $1-4$ & 15 & 16.3 & & 33 & 44.6 & \\
\hline \multirow[t]{3}{*}{ range } & $5-9$ & 48 & 52.2 & & 40 & 54.1 & \\
\hline & $10-14$ & 18 & 19.6 & & 1 & 1.4 & \\
\hline & above 14 & 11 & 12.0 & 8 & & & 5 \\
\hline Farm size range & 0.5 and below & 17 & 18.5 & & 41 & 55.4 & \\
\hline \multirow[t]{5}{*}{ (ha) } & $0.6-1.0$ & 11 & 12.0 & & 14 & 18.9 & \\
\hline & $1.1-1.5$ & 17 & 18.5 & & 3 & 4.1 & \\
\hline & $1.6-2.0$ & 7 & 7.6 & & 1 & 1.4 & \\
\hline & $2.1-2.5$ & 15 & 16.3 & & 7 & 9.5 & \\
\hline & Above 2.5 & 25 & 27.2 & 1.66 & 8 & 10.8 & 0.95 \\
\hline
\end{tabular}

Source: Field survey, 2013.

${ }^{* 1}$ EKUNWE, PA; ${ }^{1}$ OREWA, SI; ${ }^{2}$ ABULU, MO; ${ }^{1}$ EGWARE, RA 
Table II a: Profitability of maize enterprise per hectare for credit beneficiaries and non-beneficiaries

\begin{tabular}{lll}
\hline & Beneficiaries (N) & $\begin{array}{l}\text { Non-beneficiaries } \\
(\mathrm{N})\end{array}$ \\
\hline A. Total Revenue & $195,456.80$ & $168,306.39$ \\
Variable Costs Items & & \\
Agro-Chemicals & $8,072.30$ & $2,805.44$ \\
Fertilizer & $9,179.24$ & $1,185.60$ \\
Maize seeds & $1,799.68$ & $1,577.31$ \\
Labour & $20,440.86$ & $13,532.79$ \\
Transport & $5,395.36$ & $5,028.70$ \\
Total Variable Cost & $44,887.44$ & $24,129.84$ \\
(TVC) & & \\
Total Fixed Cost (TFC $=$ & $5,165.70$ & $4,997.86$ \\
T C - TVC) & & \\
Total Cost (TC) & $50,053.14$ & $29,127.70$ \\
Gross Margin & $150,569.36$ & $144,176.55$ \\
Net Profit & $145,403.66$ & $139,178.69$ \\
& & \\
\hline
\end{tabular}

Table II b: Profitability of Yam production per hectare for credit beneficiaries and non-beneficiaries

\begin{tabular}{lrr}
\hline & Beneficiaries ( & Non-beneficiaries ( $)$ \\
\hline Total Revenue & $766,087.46$ & $623,354.10$ \\
Variable cost items & & \\
Purchase of planting material & $51,441.85$ & $39,441.85$ \\
Labour & $21,477.72$ & $14,879.73$ \\
Fertilizer & $8,612.00$ & $6,075.68$ \\
Herbicide/pesticides & $6,692.07$ & $1,862.16$ \\
Transport & $3,149.46$ & $3,933.78$ \\
Total variable cost (TVC) & $91,373.10$ & $66,193.20$ \\
Total fixed cost (TFC) & $3,126.30$ & $4,232.97$ \\
Total cost & $94,499.40$ & $70,426.17$ \\
Gross Margin & $674,714.36$ & $557,160.90$ \\
Net Profit & $671,588.06$ & $552,927.93$ \\
\hline
\end{tabular}

Source: Field Survey, 2013.

Table II c: Profitability of cassava production per hectare for credit beneficiaries and non-beneficiaries

\begin{tabular}{lrr}
\hline & $\begin{array}{c}\text { Beneficiaries } \\
(\AA)\end{array}$ & $\begin{array}{r}\text { Non-beneficiaries } \\
(\AA)\end{array}$ \\
\hline Total Revenue & $567,601.48$ & $373,803.41$ \\
Variable cost items & & \\
Purchase of planting material & $7,181.67$ & $4,735.65$ \\
Labour & $125,409.17$ & $102,697.96$ \\
Fertilizer & $9,231.25$ & $5,086.33$ \\
Herbicide/pesticides & $10,650.60$ & $9,811.85$ \\
Transport & $34,807.50$ & $24,237.90$ \\
Total variable cost (TVC) & $187,280.19$ & $146,569.69$ \\
Total fixed cost (TFC) & $3,126.30$ & $4,232.97$ \\
& & \\
Total cost & $190,406.49$ & $150,802.66$ \\
Gross Margin & $380,321.29$ & $227,233.71$ \\
Net Profit & $377,194.99$ & $223,000.74$ \\
\hline
\end{tabular}

${ }^{* 1}$ EKUNWE, PA; ${ }^{1}$ OREWA, SI; ${ }^{2}$ ABULU, MO; ${ }^{1}$ EGWARE, RA 
Table II d: Profitability of plantain production per hectare for credit

\begin{tabular}{lcc}
\multicolumn{3}{c}{ beneficiaries and non-beneficiaries } \\
\hline & Beneficiaries (N) & $\begin{array}{c}\text { Non-beneficiaries } \\
\text { (N) }\end{array}$ \\
\hline Total Revenue & $761,805.75$ & $498,872.99$ \\
Variable cost items & & \\
planting material & $4,000.00$ & $3,798.50$ \\
Labour & $52,500.00$ & $39,438.90$ \\
Fertilizer & $2,000.00$ & $6,345.88$ \\
Herbicide/pesticides & $6,692.07$ & $3,290.42$ \\
Transport & $14,117.00$ & $14,090.22$ \\
Total variable cost (TVC) & $79,309.07$ & $66,963.92$ \\
Total fixed cost (TFC) & $1,080.00$ & $1,152.48$ \\
& & $68,116.40$ \\
Total cost & $80,389.07$ & $431,909.07$ \\
Gross Margin & $682,496.68$ & $430,756.59$ \\
Net Profit & $681,416.68$ & \\
\hline
\end{tabular}

Source: Field Survey, 2013

The untimely delivery of loan constituted the greatest constraint as reported by all respondents $(100 \%)$. The second major constraint was high interest rate charged as indicated by $71 \%$ of the respondents. In that order, the third constraint which was not as significant accounting for $37 \%$ of respondents was insufficient loan volume approved. Other factors that were indicated by respondents include administrative bottle necks in terms of too many application forms to fill (15.2\%), unfriendly attitude of Trust Fund Microfinance Bank workers (13\%), high cost of processing loan (10.7\%), distance to the microfinance bank $(8.7 \%)$, and lack of collateral/guarantor $(5.4 \%)$.

The non-beneficiaries identified high interest rate charge and distance as the greatest constraints to acquiring loans. Distance could pose as a major constraint to loan acquisition to the non-beneficiaries since the Trust Fund Micro Finance Bank was too far for most of them. Next, was untimely delivery of loans (77\%) and could lead to delay in loan acquisition. This delay ultimately affects production. Emerole (1995) identified untimely release of fund, cumbersome loan procedure etc as constraints that reduce the ability of clients to repay loans. This conformed to the finding of Olomola (2001) that delay in credit disbursement increases delinquency in borrows. Oke et al. (2007) proved that a day delay in micro credit disbursement will eventually reduce loan repayment rate by 0.98 percent. Furthermore, Emerole (1995) recommended that it is ideal for loan to be disbursed to farmer before the on-set of the farming period. Other constraints identified include insufficient loan approval, unfriendly attitude of Trust Fund workers, administrative bottle necks, lack of collateral/guarantor and high cost of processing loan.

\section{REFERENCES}

Adisa. B. And Okunade, E.O. (2005). Women in agricultural Extension. In Adedoyin, S.F (ed.) Agricultural Extension in Nigeria. Ilorin: Agricultural Extension. Society of Nigeria. pp. 79.

Akangbe, J. A., Ogunyinka, W., Ayanda, I. F., Achem, B. and Adisa, R. S. (2012): An Assessment of Effects of Fadama II Project on Livelihood of Farmers in Orire Local Government Area of Oyo State, Nigeria. Nigerian Journal of Agriculture, food and Environment, 8(1) 27-32.

Asiabaka, C.C. (2002). Agricultural Extension: A Hand book for Development practitioners. Omoku, Molsyfem United Services.

Dipeolu, A., Adebayo, K. and Fabohide, O. (2000). Optimal Farm plans for sustainable Environment and Economic Resource use far food Crop Farmers in UNAAB model Extension Villages. Journal of Environment Extension. 1(1), 67.

\footnotetext{
${ }^{* 1}$ EKUNWE, PA; ${ }^{1}$ OREWA, SI; ${ }^{2}$ ABULU, MO; ${ }^{1}$ EGWARE, RA
} 
EDSG (2012): Edo State Government Presentation at the Edo State Agribusiness Investment Summit. April 22,2012.

Emerole, C.O. (1995): "Demand for Institutional Credit by farmers in Abia State. A case Study of the Nigeria Agricultural and Cooperative Bank". M.Sc. Thesis, Federal University of Technology, Owerri, Nigeria

Irobi, N.C. (2008): Microfinance and Poverty Alleviation: A case study of Obazu

Progressive Women Association Mbieri, Imo StateNigeria. Uppsala: Department of Economics

Ledgerwood, J. (1999): Sustainable Banking for the Poor Project. (World Bank) South Asia.

Oke, J.T.O., Adeyemo, R. and Agbonlahor, M.U. (2007). An Empirical Analysis Of Micro Credit Repayment In South - Western Nigeria. Humanity And Social Science Journal, 2 (1): 63 74.

Olomola, A.S. (2001). "The Nature and Determinates of Rural Loan Repayment in Nigeria: The Case of FAU: Micro Credit programme", NISER Monograph series (NISER), Ibadan, P. 57.

Onemolease, E (2001), Assessment of women Farmers Access to farm Resources in Edo State. Nigeria Journal or Agricultural and social Research 1(1) $1-6$.

Robinson, M. (2001). The Microfinance Revolution: Sustainable Finance for the Poor. World Bank, Washington

Tchouassi, G. (2011). Microfinance, Inequality and Vulnerability: Empirical Analysis from Central Africa Countries. Journal of Development anf Agricultural Economics 3(4) 150-156.

Upton, M.(1992). Farm Management In Nigeria Occasional Paper, Department of Agricultural Economics, University of Ibadan, Nigeria.

USAID. (2005). Governance Issues in Microfinance. A Paper Presented at the International Year of Credit (IYMC) Workshop.

${ }^{* 1}$ EKUNWE, PA; ${ }^{1}$ OREWA, SI; ${ }^{2}$ ABULU, MO; ${ }^{1}$ EGWARE, RA 